\title{
LITERASI SENI BUDAYA MENDONGENG BONEKA TANGAN DALAM MENGEMBANGKAN KARAKTER GENERASI MILENIAL
}

\author{
Intan Sari Ramdhani ${ }^{1}$, Sumiyani ${ }^{2}$ \\ Universitas Muhammadiyah Tangerang \\ Intan.trengginas@gmail.com \\ Sumiyani@gmail.com
}

\begin{abstract}
ABSTRAK
Seni budaya memiliki kontribusi bagi pengembangan karakter generasi milenial melalui literasi seni budaya, salah satu bentuk literasi yang sedang gencar digalakkan oleh pemerintah, khususnya Kementrian Pendidikan dan Kebudayaan. Salah satu faktor yang mendasari hal tersebut terjadi adalah manusia harus menjadi manusia yang berkarakter, baik karakter kebangsaan atau karakter cinta tanah air dengan cara mencintai warisan budaya nasional. Pengenalan budaya dan penanaman nilai-nilai luhur tersebut perlu ditanamkan dari generasi ke generasi, khususnya pada generasi milenial. Generasi milenial adalah generasi yang hidup di zaman kemajuan dan perkembangan teknologi yang cukup pesat, bahkan produk teknologi itu akan mengikuti gaya hidup generasi milenial. Itu berdampak pada pergeseran perilaku dan yang lebih parah dapat mengakibatkan gaya hidup yang berbahaya sehingga mampu merusak moral kaum milenial. Maka untuk mencegah hal itu terjadi, maka penanaman dan pengembangan karakter harus terus digagas dengan menerapkan upaya atau melaksanakan program yang dapat memperkuat karakter manusia seperti mendongeng dengan media boneka tangan sebagai bentuk kecintaan dan pelestarian warisan budaya serta bentuk kontribusi seni budaya dalam mengembangkan karakter generasi penerus bangsa.
\end{abstract}

Kata Kunci : Budaya,Karakter, Generasi milenial, Seni.

\section{A. PENDAHULUAN}

Seni budaya merupakan bagian dari kebutuhan manusia. Semua hal yang berkaitan dengan peristiwa hidup manusia tidak lepas dari yang namanya seni dan budaya. Seni merupakan perbuatan manusia yang timbul dari perasaannya dan bersifat indah sehingga dapat menggerakkan jiwa dan perasaan manusia (Ki Hajar Dewantara, dalam Sugiyanto 2004:1). Sedangkan budaya adalah kompleks yang mencakup pengetahuan, kepercayaan, kesenian, moral, hukum, adat dan kebiasaan-kebiasaan yang dilakukan oleh sekumpulan anggota masyarakat (Soerjono, 2009: 150). Budaya merupakan gaya hidup yang dimiliki suatu kelompok yang memiliki ciri khas tertentu yang mencerminkan tingkah laku manusia yang berbeda-beda. Dalam dunia literasi, seni budaya merupakan salah satu ruang bermain dan belajar dengan memberikan kesempatan seluas-luasnya untuk mengembangkan kreativitas, mengeksplorasi potensi sebagai sebuah pengalaman belajar yang menyenangkan. 
Salah satu medium seni budaya adalah mendongeng. Mendongeng menjadi salah satu alternatif upaya dalam memperkenalkan warisan budaya yang dapat mempengaruhi karakter seseorang. Di zaman milenial seperti sekarang ini, yang serba canggih dan berbau produk teknologi serba ada, dimana orang-orang kecanduan internet dan lebih banyak berinteraksi dengan gadget-nya untuk bermain game, menonton video youtube atau aktif di media sosial. Budaya asyik dengan gadget atau mabuk gawai dan lekat dengan dunia maya yang terjadi pada generasi milenial ini ternyata melahirkan titik lemah. Titik lemah tersebut berdampak buruk bagi keamanan generasi milenial di dunia maya.

Walaupun generasi milenial dianggap generasi beruntung karena pada generasi ini segala fasilitas sudah siap tersedia, kemajuan dan perkembangan teknologi amat cepat, namun generasi milenial ini bisa juga dikatakan sebagai generasi yang rentan, generasi yang labil, memiliki pertahanan diri yang lemah karena terbiasa disuguhkan dengan hal-hal yang serba cepat sehingga generasi milenial lebih menyukai hal-hal yang instan tanpa merpertimbangkan risiko yang akan ia dapatkan di masa depan.Generasi milenial disebut juga generasi "strawberry”. Bak buah "strawberry”, jika sudah jatuh ke tanah maka ia akan langsung busuk. Karena memang generasi milenial itu secara fisik amat menarik, namun mudah terkontaminasi hal-hal negatif akibat pengaruh internet sehingga dapat merusak moral. Oleh sebab itu, pengembangan karakter seseorang pun menjadi terganggu.

Karakter berarti tabiat, watak sifat-sifat kejiwaan, akhlak atau budi pekerti yang membedakan seseorang dengan orang lain (Poerwadarminta dalam Syarbini, 2012:13). Karakter inilah yang akan membedakan individu yang satu dengan individu yang lainnya. Pengembangan karakter itu menjadi keberlangsungan kehidupan yang lebih baik di masa depan. Dalam proses mengembangkan karakter, seseorang perlu mengeksplorasi potensi dirinya sendiri, menghayati nilai-nilai yang menjadi kepribadian dalam bergaul di lingkungan masyarakat, mengembangkan kehidupan bermasyarakat yang lebih sejahtera dan bermartabat. Karakter identik dengan kepribadian, budi pekerti atau akhlak yang pembentukannya diterima dari lingkungan. Maka, karakter bisa juga disebut sebagai aktivitas manusia yang berhubungan dengan Tuhan, diri sendiri, sesama manusia dan lingkungan.

\section{B. LITERASI SENI BUDAYA MENDONGENG}

Seperangkat keterampilan dan kemampuan individu dalam menggali potensi dan memahamiinformasi melalui aktivitas membaca dan menulis adalah literasi. Pada hakikatnya, dengan adanya literasi dapat meningkatkan pengetahuan, meningkatkan pemahaman, kemampuan menilai kritis, menumbuhkan dan mengembangkan budi pekerti yang baik dalam 
diri seseorang serta meningkatkan nilai kepribadian seseorang. Bicara tentang budi pekerti dan kepribadian selalu dikatakan sama dengan karakter.

Oleh karena itu, literasi dapat menumbuhkan dan mengembangkan karakter seseorang. Kegiatan literasi itu bukan hanya dibatasi dari kegiatan membaca dan menulis, tetapi juga melibatkan pengetahuan Bahasa lisan dan tulisan, kemampuan kognitif, serta pengetahuan mengenai genre dan kultural. Aktivitas literasi bisa dikaitkan dengan aktivitas budaya. Menurut Hadiansyah, dkk (2017:3), literasi Budaya merupakan kemampuan dalam memahami dan bersikap terhadap kebudayaan Indonesia sebagai identitas bangsa. Literasi budaya menjadi hal yang penting untuk dikuasai di abad ke-21. Indonesia memiliki beragam suku bangsa, bahasa, kebiasaaan, adat istiadat, kepercayaan, dan lapisan sosial. Sebagai bagian dari dunia, Indonesia pun turut terlibat dalam kancah perkembangan dan perubahan global.

Oleh karena itu, kemampuan untuk menerima dan beradaptasi, serta bersikap secara bijaksana atas keberagaman ini menjadi sesuatu yang mutlak. Karena prinsipnya literasi itu mementingkan keberagaman. Seseorang harus belajar mengenal kekayaan budaya negara Indonesia dan turut serta melestarikannya. Karakter kebangsaan dan cinta tanah air bisa ditanamkan dengan mulai menjadi orang yang berbudaya. Budaya terbentuk dari banyak unsur, seperti sistem agama dan politik, adat istiadat, Bahasa, pakaian, bangunan dan kesenian. Maka, seni merupakan bagian dari budaya. Dan seni tidak bisa dipisahkan dari budaya, begitupun sebaliknya budaya juga tidak dapat dipisahkan dari seni.

Sejalan dengan itu, Hadiansyah (2017:4) juga mengatakan bahwa seni merupakan produk budaya. Seni merupakan salah satu bentuk kebudayaan yang dihasilkan oleh suatu masyarakat. Indonesia sebagai negara kepulauan yang besar tentunya menghasilkan berbagai bentuk kesenian dari berbagai daerah dengan membawa ciri khas kebudayaan dari daerahnya masing-masing. Berbagai macam bentuk kesenian yang dihasilkan oleh setiap daerah di Indonesia harus dikenalkan kepada masyarakat terutama generasi muda agar mereka tidak tercerabut dari akar budayanya dan kehilangan identitas kebangsaannya.

Seni budaya itu dapat membantu manusia dalam melangsungkan kehidupan masyarakat, karena seni budaya ini berkembang bersama dengan masyarakat. Aktivitas seni budaya dapat mengubah pola perilaku seseorang. Orang yang mempelajari seni budaya atau mengenal seni budaya maka orang itu dapat berkembang dengan gaya hidup, perilaku maupun karakter yang baik. Manusia dapat membangun dan mengembangkan karakter atau pribadi yang baik dengan menanamkan nilai-nilai pembentuk dan pengembangan karakter melalui kegiatan seni budaya. 
Salah satu kegiatan seni budaya adalah mendongeng. Menurut Priyono (2006:9), dongeng adalah cerita khayalan atau cerita yang mengada-ada serta tidak masuk akal dan dapat ditarik manfaatnya. Walau tidak masuk akal, cerita dalam dongeng memiliki informasi yang dapat ditarik manfaatnya.Dongeng juga dimaknai sebagai cerita yang diceritakan secara turun temurun dari generasi ke generasi yang bertujuan untuk menghibur dan mengajarkan nilainilai moral. Moral adalah perubahan penalaran, perasaan, dan perilaku tentang standar mengenai benar salah. Moral itu terkait dengan nilai baik dan buruk dan hal mutlak yang harus dimiliki oleh manusia atau disebut juga tindakan yang memiliki nilai positif. Karena mengandung pesan moral, maka mendongeng bisa juga mengembangkan karakter seseorang.

Oleh karena itu, dongeng dapat dijadikan media atau cara dalam mendidik seseorang dan mengajarkan seseorang tanpa harus menggurui orang tersebut. Setiap orang yang mendengar atau menyaksikan dongeng akan mengetahui pesan moral yang disampaikan lewat dongeng tersebut. Oleh karenanya, secara tidak langsung orang tersebut akan mendapatkan pelajaran yang berharga dari sebuah pesan moral sehingga mempengaruhi perilaku atau karakternya.

\section{MENDONGENG DALAM MENGEMBANGKAN KARAKTER GENERASI MILENIAL}

Mendongeng itu juga bisa menggunakan media. Media dalam mendongeng itu penting. Sejalan dengan apa yang disampaikan oleh Ralibi (2008) bahwa mendongeng itu boleh menggunakan alat peraga atau mendongeng tanpa alat peragaMedia atau alat peraga bisa membuat kegiatan mendongeng menjadi lebih menarik dan lebih hidup. Boneka tangan adalah suatu media/alat peraga yang dapat digunakan untuk mendongeng. Semakin menarik penyampaiannya, dongeng akan menjadi semakin menyenangkan dan pesan moral dalam dongeng akan cepat diterima oleh orang yang mendengarkan. Mendongeng dengan boneka tanganakanlebih menarik perhatian sehingga pendengar akan lebih memahami cerita yang disampaikan.

Hal ini juga dapat meningkatkan kreativitas seseorang dalam kegiatan mendongeng. Kegiatan mendongeng ini bisa dikatakan metode yang tepat dalam mengembangkan karakter generasi milenial yang mengalami penurunan minat membaca secara konvensional, karena generasi milenial lebih senang menonton, menonton smartphone. Kemajuan teknologilah yang menyebabkan itu terjadi, sehingga apapun yang mereka inginkan sudah ada dalam genggaman. Terutama menonton hal-hal atau tontonan-tontonan yang menarik. Saking pesatnya kemajuan teknologi, semua hal akan kalah dengan smartphone.

Kurangnya pemahaman generasi milenial terhadap dongeng terutama dongeng-dongeng tradisional, legenda, tokoh yang melegenda menjadi faktor yang mendasari bahwa 
mendongeng itu perlu dilestarikan dalam rangka mengenalkan warisan budaya kepada generasi milenial. Dengan adanya dongeng, mereka bisa belajar banyak hal. Seperti yang dikemukakan oleh Al-Qudsy dkk (2010:114), ide cerita dalam dongeng dibagi menjadi enam macam, diantaranya dongeng tradisional bersumber dari cerita rakyat atau asal-usul terjadinya suatu daerah, dongeng futuristik bersumber dari imajinasi tentang masa depan, dongeng pendidikan yang bertujuan mengubah perilaku seseorang, dongeng fabel yang sumber idenya dari hewan-hewan, dongeng sejarah yang bersumber dari sejarah para tokoh dan dongeng terapi dengan sumber idenya untuk menangani orang yang mengalami trauma terhadap suatu peristiwa.

Oleh karena itu, mendongeng itu hendaknya menyampaikan cerita yang mengandung nilai-nilai penting dan tokohnya memiliki karakter yang kuat (Ardini dalam Jurnal pengaruh dongeng dan komunikasi terhadap perkembangan moral anak usia 7-8 tahun, 2012).Dongeng menjadi upaya penguatan karakter, pengontrol kerusakan moral generasi milenial akibat terpapar budaya mabuk gawai atau budaya gadget yang dapat menyebabkan mudahnya mereka terkontaminasi atau terjun ke hal-hal negatif yang dapat merusak karakter dan moral dalam kehidupan diri sendiri atau kehidupan bermasyarakat.

\section{IMPLEMENTASI MENDONGENG BONEKA TANGAN DALAM UPAYA MENGEMBANGKAN KARAKTER GENERASI MILENIAL}

Implementasi kegiatan mendongeng itu dapat diterapkan dalam berbagai lapisan masyarakat. Oleh karena, perkembangan karakter seseorang dapat dipengaruhi oleh masyarakat. Selain di rumah dan di sekolah, lingkungan masyarakat tepat dijadikan tempat untuk menerapkan upaya dalam pengembangan karakter. Sebuah wadah yang dapat digunakan sebagai tempat untuk pembentukan karakter yaitu melalui organisasi masyarakat yang disebut dengan Karang Taruna.

Adapun Karang Taruna merupakan wadah pengembangan generasi muda yang tumbuh atas dasar kesadaran dan tanggung jawab sosial yang bergerak di bidang kesejahteraan sosial serta memiliki tujuan memberikan pembinaan dan pemberdayaan kepada para remaja. Karang taruna dirasa tepat dijadikan salah satu target penerapan kegiatan mendongeng. Itu juga memungkinkan efektivitas sasarannya lebih tepat dalam mengembangkan karakter generasi milenial. Oleh karena keseluruhan bidang yang menjadi landasan Karang taruna didirikan berkaitan erat dengan upaya pengembangan karakter.

Tujuan atau program Karang Taruna bermuara pada kesejahteraan sosial. Kesejahteraan seseorang itu dapat ditentukan oleh karakter yang dimilikinya. Kalau karakter orang itu baik, maka orang itu bisa sejahtera. Namun, Karang Taruna bisa juga jadi lingkungan berbahaya 
untuk para remaja. Karena Karang Taruna juga disebut organisasi atau kegiatan yang berbasis tidak ada kontrol dari orang tua. Kegiatan Karang Taruna bisa juga dikatakan kegiatan yang kurang adanya kontrol atau pengawasan pihak tertentu, khususnya orang tua. Orang yang tergabung dalam Karang Taruna tidak memiliki kewajiban untuk mengawasi atau mengontrol perilaku satu sama lain.

Berbeda dengan sekolah. Di sekolah, ada guru yang membantu mengawasi siswanya dan memiliki kewajiban untuk mendidik siswa agar memiliki karakter dan pribadi yang baik. Oleh karenanya, dongeng bisa dijadikan salah satu program yang dilaksanakan dalam kegiatan Karang Taruna untuk mengajarkan para remaja yang tergabung dalam Karang Taruna menjadi remaja lebih berkarakter dan bermoral, menjunjung nilai-nilai budi pekerti luhur, berprilaku baik tanpa mengguruinya. Pesan moral yang disampaikan melalui dongeng itulah yang dapat menumbuhkan dan mengembangkan karakter mereka ditengah maraknya tren generasi milenial. Hal tersebut perlu diterapkan, agar remaja mendapat pembekalan ilmu dan nilai-nilai yang baik dalam kehidupannya sehingga dapat menjadi individu yang hidup di zaman milenial yang bermanfaat, bermartabat, dan berkarakter.

Dalam hal ini, literasi seni budaya dengan media dongeng boneka tangan dianggap memiliki peran dan manfaat sebagai penunjang dalam pengembangan karakter berbasis seni dan budaya di masa yang akan datang. Melalui mendongeng, generasi milenial dapat menggunakan Bahasa lisan dan tertulis secara bersamaan dan dapat mengkomunikasikan Bahasa tubuh, gerakan dan ruang. Selain sebagai bentuk kontribusi seni dan budaya terhadap pengembangan karakter, mendongeng adalah kegiatan menuturkan atau mengisahkan tentang suatu kejadian yang disampaikan secara lisan yang akan berdampak pada aktifnya aspek intelektual, emosi, seni budaya, imajinasi dan pengembangan karakter.

\section{E. SIMPULAN}

Salah satu kontribusi seni dan budaya dalam mengembangkan karakter generasi milenial adalah mendongeng. Mendongeng merupakan kegiatan menyampaikan pesan moral. Pesan moral yang disampaikan melalui dongeng itu akan berdampak pada nilai-nilai yang dapat mempengaruhi perilaku dan karakter seseorang. Mendongeng dengan media boneka tangan dapat membantu penyampaian dongeng menjadi lebih menarik dan pesan yang disampaikan akan lebih mudah diterima. Selain sekolah, Karang Taruna menjadi salah satu alternatif target penerapan kegiatan mendongeng atau bisa juga disebut sebagai lingkungan yang tepat dalam menerapkan program mendongeng bagi para generasi milenial. Karena Karang Taruna merupakan basis kegiatan yang kurang pengawasan dan tidak terkontrol oleh orang tua. Oleh karena itu, program atau kegiatan mendongeng dengan boneka tangan harus ada dalam 
Lingua Rima: Jurnal Pendidikan Program Studi Bahasa dan Sastra Indonesia

Vol. 9 No. 1 Juli 2020

program kerja Karang Taruna dalam rangka penguatan karakter generasi milenial penerus bangsa.

\section{DAFTAR PUSTAKA}

Al-Qudsy, Muhaimin, dkk. 2010. Mendidik Anak Lewat Dongeng. Yogyakarta : Madania.

Ardini, Pupung Puspa. 2012. Pengaruh Dongeng dan Komunikasi Terhadap Perkembangan Moral Anak Usia 7-8 Tahun. Jurnal Pendidikan Anak. Universitas Negeri Gorontalo. Vol. 1, Edisi 1 tahun 2012

Hadiansyah, Firman dkk. 2017. Literasi Budaya dan Kewargaan. Jakarta : Kementrian Pendidikan dan Kebudayaan.

Priyono, Kusumo. 2006. Terampil Mendongeng. Jakarta : Grasindo.

Ralibi, Imam Maliki. 2008. Fun Teaching. Cikarang : Duha Khazanah.

Soerjono, Soekanto. 2009. Sosiologi suatu Pengantar.Jakarta: Rajawali Pers

Sugiyanto. 2004. Pengertian Seni Budaya, https://ikazakiah.wordpress.com/2012/pengertian dan- definisi-seni-budaya-menurut-para-ahli/.

Syarbini, Amirullah. 2012. Buku Pinter Pendidikan Karakter. Jakarta: as@ prima pustaka. 